\title{
Intra-Firm Wage Dispersion and Firm Performance: Evidence from Linked Employer-Employee Data
}

\author{
Thierry Lallemand, Robert Plasman and François Rycx*
}

\section{INTRODUCTION}

Relative wages are often considered as a key determinant of workers' effort. Indeed, because workers compare their wages either internally (i.e. with workers within the same firm) or externally (i.e. with workers in other firms or industries), it is argued that wage dispersion within a firm influences individual workers' productivity and thus average firm performance. However, there is no consensus regarding the precise impact of intra-firm wage dispersion on firm performance. On the one hand, the 'tournament' models (e.g. Lazear and Rosen 1981) stress the positive influence of wage inequality within a firm on the workers' effort. These models suggest the implementation of a differentiated prize structure so as to award the largest prize to the most productive worker. On the other hand, other theories argue for some degree of wage compression within a firm by emphasising the importance of fairness and cooperation among the workforce (e.g. Akerlof and Yellen 1990, Levine 1991).

\footnotetext{
* Université Libre de Bruxelles, Department of Applied Economics (DULBEA) and Centre de Comptabilité, Planning et Contrôle, CP 135 - Av. F.D. Roosevelt 50, 1050 Brussels, Belgium, e-mail: thierry.lallemand@ulb.ac.be. Université Libre de Bruxelles, Department of Applied Economics (DULBEA), CP 140 - Av. F.D. Roosevelt 50, 1050 Brussels, Belgium, e-mail: rplasma@ulb.ac.be, frycx@ulb.ac.be. This paper is produced as part of a TSER programme on Pay Inequalities and Economic Performance (PIEP) financed by the European Commission (Contract nr. HPSE-CT-1999-00 040). It has evolved from earlier versions presented at the PIEP meetings (July 2003, London School of Economics and January 2004, Université Libre de Bruxelles) and the 9th Annual Meeting of the Society of Labor Economists (April 2004, San Antonio - Texas). We are most grateful to D. Cecchi, C. Dell'Aringa, C. Lucifora, D. Marsden and J. Prinz for helpful suggestions. We also thank an anonymous referee for valuable comments. Finally, we would like to thank Statistics Belgium for giving access to the 'Structure of Earnings Survey' and the 'Structure of Business Survey'. The usual disclaimer applies.
} 
Empirical studies, focusing on the relationship between wage disparities and firm performance, are not very numerous and their results vary significantly. Due to a lack of appropriate data, these studies often rely on economy-wide inequality indicators or make use of 'self-constructed' instruments for firm performance. Moreover, they are generally restricted to a particular segment of the labour force (e.g. the top-management level) or a specific sector of the economy (e.g. the manufacturing sector, academic departments, professional team sports). In sum, the available evidence does not appear to be very compelling yet (Frick et al. 2003).

The aim of this paper is to examine the relationship between intra-firm wage dispersion and firm performance in the Belgian private sector. Our analysis is based on a unique matched employer-employee data set. This data set derives from the combination of the 1995 Structure of Earnings Survey and the 1995 Structure of Business Survey. The former contains detailed information on firm characteristics (e.g. sector of activity, size of the firm, and level of wage bargaining) and on individual workers (e.g. gross hourly wages, bonuses, age, education, sex, and occupation). The latter provides firm-level information on financial variables (e.g. gross operating surplus, value added, and value of production).

Our methodology is consistent with that of Winter-Ebmer and Zweimüller (1999). It rests upon a two-step estimation procedure. Firstly, we compute conditional intra-firm wage differentials by taking the standard errors of wage regressions run for each firm. Next, we use these conditional wage differentials as an explanatory variable in a firm-level performance regression. However, as a sensitivity test, we also analyse the impact of unconditional indicators of intra-firm wage dispersion on firm performance. These indicators include the standard deviation, the coefficient of variation and the max-min ratio of the gross hourly wages within the firm. The performance of a firm is measured by the gross operating surplus per worker. It is a good proxy for the firm's per capita profits. We address the potential simultaneity problem between profits and wage dispersion using information from the Belgian income tax system. More precisely, we use two-stage least squares (2SLS) and instrument the dispersion of wages including bonuses by the intra-firm standard deviation of income taxes on gross earnings excluding bonuses.

The first step of Winter-Ebmer and Zweimüller's (1999) estimation procedure requires a large number of data points per firm. Therefore, our sample has been restricted to firms with at least 200 workers. This restriction guarantees a minimum of 10 observations per firm. Our definitive sample is representative of all firms employing at least 200 workers within sections D to K of the Nace Rev. 1 nomenclature, with the exception of hotels and restaurants $(\mathrm{H})$ and the 
financial sector $(J)^{1}$. It covers 17490 individuals working for 397 firms. To our knowledge, this paper is one of the first to examine the effect of intra-firm wage dispersion on firm performance in the private sector using both a conditional wage inequality indicator and direct information on firm performance. It is also one of the few, with Bingley and Eriksson (2001) and Heyman (2002), to consider potential simultaneity problems.

The results presented in this paper support the existence of a positive and significant relationship between wage inequality and firm performance. Moreover, we find that the intensity of this relationship is larger for blue-collar workers and within firms with a high degree of monitoring. These findings are more in line with the 'tournament' models than with the 'fairness, morale and cohesiveness' models.

The remainder of this paper is organised as follows. Section II reviews the literature (both theoretical and empirical) dealing with the effects of intra-firm wage dispersion on firm performance. Sections III and IV present the methodology and the data set. Section V discusses the results. The last section concludes.

\section{BACKGROUND}

\section{Theory}

A first interpretation of the relationship between within-firm wage dispersion and firm performance has been provided by Akerlof and Yellen (1988). On the basis of the effort version of the 'efficiency wage' theory (Solow 1979), the authors argue that in a firm where the workers' characteristics are not totally observable and where monitoring of their actions is not perfect, employers have to find well-suited incentives to maximise workers' effort. According to Akerlof and Yellen (1988), the effort function of a worker can be written as follows: $e=e\left(\sigma^{2}(w)\right)$, where $e$ denotes the level of effort and $\sigma^{2}(w)$ the variance of wages within the firm. This expression shows that a worker's effort does not only depend on the wage level but also on the degree of salary dispersion within

1. Our sample is representative of all firms employing at least 200 workers within the following sectors: i) manufacturing (D), ii) electricity, gas and water supply (E), iii) construction (F), iv) wholesale and retail trade; repair of motor vehicles, motorcycles and personal and household goods $(\mathrm{G}), \mathrm{v}$ ) transport, storage and communication (I), and vi) real estate, renting and business activities $(\mathrm{K})$. The mining and quarrying sector $(\mathrm{C})$ and the hotels and restaurants $(\mathrm{H})$ are not part of our final sample because almost all firms in these sectors employ less than 200 workers. 
the firm. Using this expression, the authors argue that a compressed wage distribution improves labour relations and stimulates the average workers' effort. To put it differently, firms should achieve, on average, a greater output per worker if wage dispersion is low. Later, Akerlof and Yellen (1990) developed the 'fair wage-effort' hypothesis. This hypothesis clarifies their previous reasoning by developing in greater detail the notion of fairness and introducing the concept of relative wages ${ }^{2}$. The basic idea is that workers often compare their wages either internally (i.e. with workers within the same firm) or externally (i.e. with workers in other firms or industries). Therefore, Akerlof and Yellen (1990) consider the following worker's effort function: $e=\min [(w / \hat{w}), 1]$, with $w$ the actual wage, the fair wage and $e$ equal to one if the level of effort is normal. This expression shows that workers reduce their effort if their actual wage falls short of the wage they regard as fair. According to the authors, a wage is generally considered as fair if the pay spread is lower than the performance differential. Levine (1991) put forward this argument by stressing that pay compression within a firm where teamwork among employees is essential (i.e. participatory firms), sustains and stimulates cohesiveness which increases the firm's total productivity.

The above notions of fairness, morale and cohesiveness led Hibbs and Locking (2000) to define the following firm-level production function: $Q=\operatorname{Ef}\left[\sigma^{2}\right.$ (w)] $\mathrm{F}(\mathrm{L}, \ldots)$, with $Q$ the real value added, $E f($.$) the labour effectiveness de-$ pending on within-firm wage dispersion, $F$ a standard production function and $L$ the labour inputs to production. This expression shows that the performance of a firm depends positively upon the efficiency of labour, which is negatively correlated with intra-firm wage dispersion (i.e. $E f^{\prime}\left(0, E f^{\prime \prime}>0\right)$. As a result, this model of 'fairness, morale and cohesiveness' suggests that firms have a strong incentive to implement a wage distribution that is more compressed than the variation in workers' productivities.

A complementary theory promoting wage compression to increase firm performance has been developed by Milgrom (1988), and Milgrom and Roberts (1990). The authors emphasize that (white-collar) workers have incentives to: i) withhold information from managers in order to increase their influence and, ii) engage in costly rent-seeking activities instead of productive work. They also argue that the implementation of some degree of wage equity can reduce the potential tendency of workers to take personal interest decisions which may not be profitable for the organisation as a whole. Moreover, they stress that

2. The 'fair wage-effort' hypothesis is based on the social exchange theory in sociology (e.g. Blau 1955, Homans 1961) and on the equity theory in psychology (e.g. Adams 1963). Both theories show the existence of a relationship between effort and fairness. 
it is more costly to monitor the actions of white-collar workers. Therefore, lower levels of wage dispersion are thought to be even more important for the latter.

In contrast to the previous literature, the 'relative compensation' or 'tournament' model, developed by Lazear and Rosen (1981), points to the benefits of a more dispersed wage structure, deriving from a performance-based pay system. This model suggests that managers should introduce a large spread in the rewards of workers in order to stimulate their effort. In other words, firms should establish a differentiated prize structure and award the largest prize to the most productive worker ${ }^{3}$. Formally, Lazear and Rosen (1981) consider two identical risk-neutral workers and a risk-neutral firm, with a compensation scheme such that the most productive worker receives a high wage $\left(W_{H}\right)$ and the least productive a low wage $\left(W_{L}\right)$. On the basis of these assumptions, the authors show that, ceteris paribus, workers' optimal level of effort: i) increases with prize dispersion $\left(W_{H}-W_{L}\right)$, and ii) decreases with the random component of output (e.g. luck) ${ }^{4}$. This model has been generalized by McLaughlin (1988) for $n$ players. The author shows that the number of players matters and that the probability to win a game decreases with the number of contestants. Consequently, to stimulate workers' effort, there should be a positive correlation between the prize spread and the number of contestants.

Lazear $(1989,1995)$ argues, however, that high within-firm wage dispersion generates more competition between the workers which may negatively affect firm performance. Indeed, considering an organisation in which some workers are non-cooperative or have a sabotage behaviour ('hawks') while others are less aggressive ('doves'), the author shows that wage compression is crucial for firm performance ${ }^{5}$. The point is that the non-cooperative activities adopted by the 'hawks' reduce the total effort level of the workers. In other words, the positive impact of an output-based pay system on firm performance may be offset by a lower level of work cohesion due to the sabotage behaviour of 'hawks'. As a result, it appears profitable for a firm to: i) adequately sort out workers before hiring them and ii) adjust the compensation scheme to the hierarchical level.

A further strand of the literature, developed by Frey (1997) and Frey and Osterloh (1997), focuses on the interplay between wage dispersion and intrinsic

3. There is some ambiguity in the literature about the definition of a prize. It can be seen either as a promotion (i.e. to get a task with higher responsibilities and to rise in the firm hierarchy) or as a bonus.

4. For a discussion of Lazear and Rosen's (1981) model see Gibbons and Waldman (1999).

5. According to Lazear $(1989,1995)$, 'hawks' are often found at the top level of the organisation, i.e. mainly among white-collar workers. His arguments are thus in line with those of Milgrom (1988) and Milgrom and Roberts (1990). 
motivation $^{6}$. This literature shows that the implementation of explicit incentive contracts (e.g. performance-based pay systems) can crowd out the intrinsic motivation of the workers by generating excessive external monitoring (in particular, for workers who need autonomy in their job and who have high responsibilities). However, it can also enhance intrinsic motivation by supporting the workers' own motivation, self-esteem and feeling of competence. In sum, this literature emphasizes the importance of a correct match between the compensation scheme and the monitoring environment within a firm (Belfield and Marsden 2003).

\section{Previous results}

Empirical studies focusing on the relationship between wage disparities and firm performance are small in number and their results vary significantly. Due to a lack of appropriate data, these studies often rely on economy-wide inequality indicators or make use of 'self-constructed' instruments for firm performance. Moreover, they are generally restricted to a particular segment of the labour force (e.g. the top-management level) or a specific sector of the economy (e.g. the manufacturing sector, academic departments, professional team sports).

A first strand of the empirical literature provides evidence in favour of the 'fairness, morale and cohesiveness' theory, developed by Akerlof and Yellen (1990) and Levine (1991).

Cowherd and Levine (1992), for instance, examine the relationship between interclass pay equity and the performance of business units, building on the body of equity, relative deprivation and quality management theories ${ }^{7}$. Their study is based on data collected from 102 business units with more than $59 \mathrm{em}-$ ployees in North America (72\%) and Europe (28\%). The performance of a business unit is measured by the quality of its production ${ }^{8}$. According to the authors, product quality is a good indicator of firm performance since it is: i) difficult for managers to control, and ii) a function of the willingness of lower-

6. It derives from the psychological literature which suggests that intrinsic motivation is the main driving force of workers' effort.

7. Interclass pay equity is measured by the pay relation of hourly paid employees to top-three levels of management, controlling for the business size effect. A business unit is defined as any autonomous organisational unit that has top management with decision-making authority in areas like manufacturing and sales.

8. The latter is measured by customers in relative terms, i.e. in comparison with the product quality of the main competitors of each business unit. 
level employees to contribute more than can formally be asked from them. Their empirical findings show the existence of a substantial positive relationship between interclass pay equity and product quality. The authors attribute this result to the impact of pay equity on three aspects of lower-level employee motivation, i.e. commitment to managerial goals, effort and cooperation.

Pfeffer and Langton (1993) analyse how within-academic departments wage dispersion and pay schemes affect the individual's satisfaction, research performance and cooperation, using a large sample of college and university faculty in the UK ${ }^{9}$. Their data set contains information on circa 17000 college and university professors from 600 academic departments located in some 300 institutions ${ }^{10}$. Salary dispersion is measured by an unconditional indicator, i.e. the coefficient of variation (the standard deviation divided by the mean) in salaries within a given academic department. Controlling for numerous predictors, the authors observe both statistically and substantively significant negative effects of pay dispersion. To put it differently, they find that, on average, people are less satisfied, collaborate less on research, and have a lower productivity when pay distribution is more dispersed. Moreover, results show that the extent to which wage dispersion produces adverse effects depends upon one's position in the salary structure and factors such as information, commitment, consensus and the level of certainty in the evaluation process.

A number of studies, essentially concentrated on the US, have assessed the interaction between salary dispersion and performance in the team sports industry. Using mainly unconditional measures of wage inequality (e.g. the Giniindex), these studies generally conclude that pay compression is beneficial for team performance (e.g. the win-loss percentage) ${ }^{11}$. The study of Frick et al. (2003) is the first to attempt to measure the impact of pay inequalities on the performance of professional team sports across different leagues. Their approach allows to implicitly control for the influence of different institutional regimes and production technologies. Using panel data from the four major North American sports leagues (i.e. baseball, basketball, football, and hockey), their study supports neither the 'fairness, morale and cohesiveness' hypotheses nor the 'tournament' theories. Indeed, their findings vary substantially between the four leagues. According to their estimates, a higher degree of intra-team

9. The data come from the Carnegie Commission's 1969 survey of college and university faculty.

10. The authors confined their attention to respondents in departments with a size of 20 or larger that had a response rate to the questionnaire greater than $50 \%$.

11. For professional baseball teams, see Bloom (1999), DeBrock et al. (2001), Depken (2000), Harder (1992) or Richards and Guell (1998). For soccer and hockey teams, see respectively Lehmann and Wacker (2000) and Gomez (2002). 
wage dispersion is beneficial to the performance of professional basketball and hockey teams ${ }^{12}$. However, the reverse relationship is found to be true for football and baseball teams, i.e. a team is more successful if its pay distribution is more compressed. The authors explain this diversity in results by differing 'cooperation requirements' in the four leagues.

Another strand of the empirical literature provides evidence in favour of the 'tournament' theory, developed by Lazear and Rosen (1981). Winter-Ebmer and Zweimüller (1999), for instance, investigate the impact of intra-firm wage dispersion on firm performance using panel data covering the whole Austrian workforce over the period 1975-91 ${ }^{13}$. They measure within-firm wage inequality by the standard errors of firm-level wage equations. This conditional indicator controls for the composition of the workforce within each firm ${ }^{14}$. Unfortunately, the authors did not observe the financial performance of the firms. As a result, they have constructed their own performance indicator, i.e. standardised wages. Of course, this instrument is not perfectly adequate. Be it as it may, after controlling for several predictors, their findings suggest the existence of a positive and hump-shaped relationship between intra-firm wage dispersion and firm performance, for both blue- and white-collar workers. Yet, the overall pattern appears to be more monotonic for blue-collar workers. These findings are in line with the hypothesis that too little wage inequality negatively affects firm performance due to a lack of incentives. However, they also suggest that excessive wage dispersion can be harmful for productivity because of fairness effects. According to the authors, the contrasting results for blue- and white-collar workers appear to be consistent both with theories of intrinsic motivation and rent-seeking, and with the prevalence of piece rates in blue-collar jobs.

Hibbs and Locking (2000) examine the effects of changes in the overall wage dispersion, during the periods 1964-93 and 1972-93, on the productive efficiency of Swedish industries and plants. To do so, they firstly decompose the total variance in individual wages within and between plants (and industries). Next, they integrate the squared coefficients of variation of these components at the plant (or industry) level in an Akerlof and Yellen's (1990) type of production function. The dependent variable in this equation, i.e. their perform-

12. For hockey teams, the coefficient is positive but not significantly different from zero.

13. Their sample is restricted to firms with more than 20 employees and with at least 4 data points.

14. The data report monthly earnings that are top coded. The explanatory variables in the tobit wage regressions, run separately for each firm, include age, age squared, and dummies for sex, blue-collar, foreigner, and two tenure dummies. Information on education levels is not available. 
ance indicator, is the log of real value added at the plant (or industry) level ${ }^{15}$. Their empirical findings do not confirm that wage levelling within plants and industries enhances productivity. Therefore, they do not support the 'fairness, morale and cohesiveness' theories.

Bingley and Eriksson (2001) analyse the impact of pay spread and skewness on two performance indicators, i.e. firm productivity and employee effort. Their study uses longitudinal matched employer-employee data comprising information on Danish medium-and large private sector firms during the period 1992-95. It is the first to address potential simultaneity problems using information from the income tax system. Firm productivity and employee effort are estimated by the total factor productivity and the sickness absence, respectively. Differences in firm productivity effects between the occupational groups and types of firms give support to the theories of fairness, tournaments and tastes for skewness. In contrast, individual effort effects only back up the tournament theory.

Finally, a number of papers present evidence on the interaction between the pay structure of top executives and firm performance. Focusing on managers in large US firms, Leonard (1990) finds no significant relationship between the standard deviation of pay and firm performance, i.e. the return on investment. In contrast, using respectively US and Swedish data, Main et al. (1993) and Eriksson (1999) report a positive impact of top executive pay dispersion on firm performance. The latter is measured by returns on assets and the profits/ sales ratio, respectively. The paper of Heyman (2002) is the first to explicitly control for firm-level differences in human capital when testing several predictions from the tournament theory for white-collar workers and in particular managers ${ }^{16}$. On the basis of a large matched employer-employee data set for the Swedish economy in 1991 and 1995, the author finds a positive effect of wage dispersion on profits.

15. Their production function is as follows: $\ln [Q]=\ln \left[E f\left(\sigma^{2}(w)\right) F().\right]$, where $\left.E f\left(\sigma^{2}(w)\right)\right)=$ $E f\left(C V^{2}(W), C V^{2}(B)\right)$. In this expression, $Q$ represent the real value added, $E f($.$) the labour ef-$ fectiveness depending on $\sigma^{2}(w)$ (i.e. the total variation in individual wages), and $F($.$) a standard$ production function (e.g. Cobb-Douglas, CES or Translog). $C V^{2}(W)$ and $C V^{2}(B)$ stand respectively for the within and between components of the total variance of individual wages (squared coefficient of variation) among workers assortment by plants (or industries).

16. His conditional indicator of wage dispersion is the same as in Winter-Ebmer and Zweimüller (1999). 


\section{METHODOLOGY}

There are several ways to compute intra-firm wage inequality. On the one hand, wage dispersion can be measured between unequal workers by unconditional indicators (e.g. the Gini index, the white/blue-collar wage ratio, or the pay gap between managers and the rest of the workforce). On the other hand, it can be defined for workers with similar observable characteristics. In this case, wage dispersion is measured by the residual inequality, after controlling for human capital variables.

Although unconditional indices may have appeal if the analysis focuses on the effect of CEO's pay on firm performance, many theories like 'tournaments' or 'hawks and doves' refer to wage differentials between similar workers (Winter-Ebmer and Zweimüller 1999). As a result, a conditional indicator appears more appropriate for our study. Hence, we follow the methodology developed by Winter-Ebmer and Zweimüller (1999). However, as a sensitivity test, we also analyse the impact of three unconditional indicators of intra-firm wage dispersion on firm performance. These indicators include the standard deviation, the coefficient of variation and the max-min ratio of the gross hourly wages within the firm.

The methodology of Winter-Ebmer and Zweimüller (1999) rests upon a two-step estimation procedure. In the first step, we estimate by OLS the following wage equation for each firm:

$$
\ln \mathrm{W}_{i j}=\alpha_{0}+\alpha^{\prime} \mathrm{Y}_{i j}+\varepsilon_{i j}
$$

where $W_{i j}$ is the gross hourly wage including bonuses of worker $i$ in firm $j, Y_{i j}$ is a vector of individual characteristics including age, age squared, sex, education (two dummies), and occupation (one dummy), and $\varepsilon_{i j}$ is the usual error term. The standard errors of these regressions $\left(\sigma_{j}\right)$ are used as a measure of conditional intra-firm wage dispersion.

In the second step, we estimate by OLS the following firm-level performance regression:

$$
\ln \mathrm{P}_{j}=\beta_{0}+\beta_{1}^{\prime} \sigma_{j}+\beta_{2}^{\prime} \mathrm{X}_{j}+\beta_{3}^{\prime} \mathrm{Z}_{j}+v_{j}
$$

where $P_{j}$ is the performance of firm $j, \sigma_{j}$ is the conditional indicator of the intrafirm wage dispersion, $X_{j}$ contains aggregated characteristics of workers, $Z_{j}$ includes employer characteristics and $v_{j}$ is the usual error term. The performance of a firm $\left(P_{j}\right)$ is measured by the gross operating surplus per worker. It is a good proxy of the firm's per capita profits. It is obtained by subtracting total person- 
nel expenses from value added at factor costs. The main explanatory variable in equation (2) is the conditional intra-firm wage dispersion $\left(\sigma_{j}\right)$ estimated in step 1. Equation (2) contains numerous control variables for the composition of the workforce $\left(X_{j}\right)$ as well as for firm characteristics $\left(Z_{j}\right)$. These control variables include the share of the workforce that: i) at most has attended lower secondary school, ii) has more than 10 years of tenure, and iii) is younger than 25 and older than 50 years, respectively. The share of women, the share of bluecollar workers, the share of workers supervising co-workers, sectoral affiliation (5 dummies), the size of the firm (the number of workers), and the level of wage bargaining (2 dummies) are also included.

An important problem to consider is the potential simultaneity between profits and wage dispersion. Indeed, it may be argued that highly profitable firms pay higher bonuses, which in turn leads to more wage inequality. We address this issue using information from the income tax system. More precisely, we use two-stage least squares (2SLS) and instrument the dispersion of wages including bonuses by the intra-firm standard deviation of income taxes on gross earnings excluding bonuses. Of course, it is very difficult to find an appropriate instrument for intra-firm wage inequality. However, we believe that our instrument is of potential interest for breaking the simultaneity problem since it is less affected by profit-sharing. In other words, we expect the intra-firm standard deviation of income taxes on gross earnings excluding bonuses to be uncorrelated (or at least less correlated) with the error term and highly correlated with the endogenous variable (i.e. wage dispersion). Statistics on workers' income taxes, available in our data set, refer to the same year as profits and incomes, i.e. 1995. They have been estimated by Statistics Belgium. To do so, Statistics Belgium relied on individual gross annual earnings, excluding bonuses and social security contributions (13.07\%). After deduction of professional costs, they obtained the assessable income. From this, they derived the base income tax ( 7 different scales), the municipality taxes $(7 \%)^{17}$, the supplementary crisis contribution (3\%) and the special social security contribution (6 different scales). The sum of these four elements provides an estimation of the individual income taxes ${ }^{18}$.

17. Statistics Belgium had no information on the workers municipality of residence. Therefore, they applied the average municipality tax (7\%) to all employees.

18. The most important restriction of these estimates is that they do not consider the specific situation of the employee, e.g. composition of the family. For more information see Demunter (2000). 


\section{DATA}

Our analysis is based upon a unique combination of two large-scale data sets. The first, carried out by Statistics Belgium, is the 1995 'Structure of Earnings Survey' (SES). It covers all Belgian firms employing at least 10 workers and with economic activities within sections $\mathrm{C}$ to $\mathrm{K}$ of the Nace Rev. 1 nomenclature. The survey contains a wealth of information, provided by the management of the firms, both on firm-level characteristics (e.g. sector of activity, size of the firm, and level of wage bargaining) and individual workers (e.g. age, education, gross hourly wages, sex, and occupation). Unfortunately, it provides no financial information. Therefore, the SES has been merged with the 1995 'Structure of Business Survey' (SBS). It is a firm-level survey, conducted by Statistics Belgium, with a different coverage than the SES in that it includes neither the financial sector (Nace J) nor firms with less than 20 employees. The SBS provides firm-level information on financial variables such as sales, value added, production value, gross operating surplus and value of purchased goods and services.

The first step of our estimation procedure requires a large number of data points per firm. Therefore, our sample has been restricted to firms with at least 200 workers. This restriction guarantees a minimum of 10 observations per firm. Our definitive sample is representative of all firms employing at least 200 workers within sections D to K of the Nace Rev. 1 nomenclature, with the exception of hotels and restaurants $(\mathrm{H})$ and the financial sector $(\mathrm{J})$. It covers 17490 individuals working for 397 firms. The mean number of data points per firm is 44 and for $75 \%$ of the firms there are between 10 and 41 observations.

Table 1 depicts the means and standard deviations of selected variables ${ }^{19}$. We note that, on average, firms' annual profits per employee amount to 23000 EUR and that the residual pay inequality is equal to 0.17 . Moreover, we find that the estimated intra-firm wage dispersion is highest when measured by the max-min ratio, that the mean age is around 37 years, and that, on average, approximately $26 \%$ of the workers are women, $48 \%$ are blue-collar, and $42 \%$ have a low level of education (i.e. lower secondary school at most). Finally, Table 1 shows that, on average, firms employ 480 workers and are essentially concentrated in the manufacturing sector (64\%); wholesale and retail trade, repair of motor vehicles (19\%); and real estate, renting and business activities $(11 \%)$.

19. For a detailed description see Tables A1 and A2 in the Appendix. 


\section{INTRA-FIRM WAGE DISPERSION AND FIRM PERFORMANCE}

Table 1

Means and Standard Deviations of Selected Variables ${ }^{+}$

\begin{tabular}{|c|c|c|}
\hline Variables & Mean & SD \\
\hline Profits per employee ${ }^{1}$ (in thousands of EUR) & 23.0 & $1,205.7$ \\
\hline Residual pay inequality ${ }^{2}$ & 0.17 & 0.07 \\
\hline Standard deviation of wages ${ }^{3}$ & 0.24 & 0.10 \\
\hline Coefficient of variation of wages ${ }^{3}$ & 0.29 & 0.14 \\
\hline Max-min ratio of wages ${ }^{3}$ & 3.17 & 1.60 \\
\hline Age (years) & 37.2 & 9.6 \\
\hline Female & 25.9 & \\
\hline \multicolumn{3}{|l|}{ Education } \\
\hline No degree, primary/lower secondary & 41.5 & \\
\hline $\begin{array}{l}\text { General upper secondary, technical/artistic/prof. upper sec- } \\
\text { ondary }\end{array}$ & 38.8 & \\
\hline Higher non university, university and post graduate & 19.7 & \\
\hline Blue-collar workers & 48.4 & \\
\hline Size of the firm (number of workers) & 480.4 & 621.1 \\
\hline \multicolumn{3}{|l|}{ Sector } \\
\hline Manufacturing (D) & 63.5 & \\
\hline Electricity, gas and water supply (E) & 0.2 & \\
\hline Construction $(\mathrm{F})$ & 3.6 & \\
\hline Wholesale and retail trade; repair of motor vehicles $(\mathrm{G})$ & 18.6 & \\
\hline Transport, storage and communication (I) & 3.7 & \\
\hline Real estate, renting and business activities $(\mathrm{K})$ & 10.6 & \\
\hline Number of employees & \multicolumn{2}{|c|}{17,490} \\
\hline Number of firms & \multicolumn{2}{|c|}{397} \\
\hline \multicolumn{3}{|c|}{$\begin{array}{l}\text { Notes: + The descriptive statistics refer to the weighted sample. } \\
1 \text { Estimated by the firm annual gross operating surplus per worker. } \\
2 \text { Conditional measure of the intra-firm wage dispersion (i.e. standard errors of wage regressions } \\
\text { run for each firm separately). } \\
3 \text { Individual gross hourly wages include overtime paid, premiums for shift work, night work and/or } \\
\text { weekend work and bonuses, i.e. irregular payments which do not occur during each pay period, such } \\
\text { as pay for holiday, 13th month, and profit sharing. }\end{array}$} \\
\hline
\end{tabular}

\section{RESULTS}

\section{Basic specification}

Table 2 reports our estimates of the effect of wage dispersion on firm performance. These estimates are obtained by applying respectively OLS and 2SLS, with White (1980) heteroscedasticity consistent standard errors, to equation (2). 
THIERRY LALLEMAND/ROBERT PLASMAN/FRANÇOIS RYCX

Table 2

Firm-level Performance Regressions, OLS vs. 2SLS

\begin{tabular}{|c|c|c|c|c|c|c|c|c|}
\hline Dependent variable & & & Pro & fits per en & aployee ${ }^{1}($ & ln) & & \\
\hline & & $\mathrm{Ol}$ & $\mathrm{LS}$ & & & $2 \mathrm{~S}$ & LS & \\
\hline Intercept & $\begin{array}{l}5.92 * * \\
(0.66)\end{array}$ & $\begin{array}{l}5.86^{* *} \\
(0.66)\end{array}$ & $\begin{array}{l}5.99 * * \\
(0.66)\end{array}$ & $\begin{array}{l}6.37 * * \\
(0.65)\end{array}$ & $\begin{array}{l}5.26^{* *} \\
(0.63)\end{array}$ & $\begin{array}{l}5.53 * * \\
(0.65)\end{array}$ & $\begin{array}{l}5.67 * * \\
(0.66)\end{array}$ & $\begin{array}{l}6.61 * * \\
(0.67)\end{array}$ \\
\hline $\begin{array}{l}\text { Residual pay } \\
\text { inequality }{ }^{2}\end{array}$ & $\begin{array}{r}2.04^{*} \\
(0.99)\end{array}$ & & & & $\begin{array}{l}8.73 * * \\
(2.10)\end{array}$ & & & \\
\hline $\begin{array}{l}\text { Standard deviation } \\
\text { of wages }^{3}\end{array}$ & & $\begin{array}{l}1.81 * * \\
(0.67)\end{array}$ & & & & $\begin{array}{l}4.17 * * \\
(0.98)\end{array}$ & & \\
\hline $\begin{array}{l}\text { Coefficient of } \\
\text { variation of wages }\end{array}$ & & & $\begin{array}{r}0.87^{\circ} \\
(0.46)\end{array}$ & & & & $\begin{array}{l}2.93 * * \\
(0.72)\end{array}$ & \\
\hline $\begin{array}{l}\text { Max-min ratio of } \\
\text { wages }^{3}\end{array}$ & & & & $\begin{array}{l}0.14 * * \\
(0.04)\end{array}$ & & & & $\begin{array}{l}0.27 * * \\
(0.06)\end{array}$ \\
\hline $\begin{array}{l}\text { Worker } \\
\text { characteristics }^{4}\end{array}$ & Yes & Yes & Yes & Yes & Yes & Yes & Yes & Yes \\
\hline $\begin{array}{l}\text { Firm } \\
\text { characteristics }^{5}\end{array}$ & Yes & Yes & Yes & Yes & Yes & Yes & Yes & Yes \\
\hline Adjusted $\mathrm{R}^{2}$ & 0.39 & 0.39 & 0.38 & 0.40 & 0.34 & 0.39 & 0.38 & 0.40 \\
\hline F-stat & $69.11^{* *}$ & $71.78 * *$ & $68.09 * *$ & $71.15^{* *}$ & $81.81 * *$ & $78.54 * *$ & $73.77 * *$ & $76.60 * *$ \\
\hline $\begin{array}{l}\text { Hausman test: } \\
\text { p-value }\end{array}$ & & & & & 0.00 & 0.00 & 0.00 & 0.00 \\
\hline $\begin{array}{l}\text { Number of } \\
\text { employees }\end{array}$ & 17,490 & 17,490 & 17,490 & 17,490 & 17,490 & 17,490 & 17,490 & 17,490 \\
\hline Number of firms & 397 & 397 & 397 & 397 & 397 & 397 & 397 & 397 \\
\hline
\end{tabular}

Notes: $* * / * /{ }^{\circ}$ indicate significance at the 1,5 and $10 \%$ level, respectively. White (1980) heteroscedasticity consistent standard errors are reported between brackets.

1 Estimated by the firm annual gross operating surplus per worker.

2 Conditional measure of the intra-firm wage dispersion (i.e. standard errors of wage regressions run for each firm separately).

3 Individual gross hourly wages include overtime paid, premiums for shift work, night work and/or weekend work and bonuses, i.e. irregular payments which do not occur during each pay period, such as pay for holiday, 13th month and profit sharing.

4 Share of the workforce that: i) at most has attended lower secondary school, ii) has more than 10 years of tenure and iii) is younger than 25 and older than 50 years, respectively. The share of women, the share of blue-collar workers and the share of the workers supervising co-workers are also included.

5 Sectoral affiliation ( 5 dummies), size of the firm (number of workers), and level of wage bargaining (2 dummies). 
Findings, obtained from OLS regressions, emphasize the existence of a positive and significant relationship between intra-firm wage dispersion and firm performance. The intensity of this relationship is strongest when the wage differential is computed for workers with similar observable characteristics (i.e. with the residual pay inequality). Overall, the point estimates range between 2.04 and 0.14 , which yields an elasticity of between 0.44 and 0.25 at sample means. These results suggest that, on average, a rise of $10 \%$ in wage inequality increases firm performance by between 4.4 and $2.5 \%{ }^{20}$. Yet, it could be argued that because of the potential simultaneity between profits and wage dispersion, OLS estimates are not only biased but also inconsistent ${ }^{21}$. To account for this problem, we run 2SLS regressions instrumenting the dispersion of wages including bonuses by the intra-firm standard deviation of income taxes on gross earnings excluding bonuses. Results from these regressions, presented in Table 2, confirm the positive and significant impact of wage dispersion on profits. Moreover, we find that the elasticity between wage dispersion and profits is significantly larger when using $2 \mathrm{SLS}^{22}$. At sample means, the elasticity now stands at between 1.48 and 0.87 . This means that, on average, when wage dispersion increases by $1 \%$, firm performance rises by between 1.48 and $0.87 \%$.

How are we to interpret these results? The positive impact of wage dispersion on firm performance tends to support the 'tournament' models (Lazear and Rosen 1981). Indeed, these models demonstrate that if the workforce is rela-

20. Similar positive and significant results have been found for the unconditional indicators when we extended our sample to all firms with 20 workers or more (results are available on request). Yet, due to a limited number of data points within small firms, we are not able to determine whether this is also the case using a conditional indicator.

21. Hausman's (1976) specification error tests, reported in Table 2, support the existence of a simultaneity problem.

22. A similar result has been found by Heyman (2002).

23. To test for a hump-shaped relationship, three methods have been used. Firstly, we added withinfirm wage inequality indicators in quadratic form to our regression model. Results obtained with OLS were inconclusive because of a strong multicollinearity between indicators in level and squared. However, 2SLS estimates showed a significant positive and hump-shaped pattern for two instrumented wage inequality indicators, i.e. the standard deviation and the coefficient of variation of wages. Next, we divided our sample into two homogenous parts containing low and high inequality firms, respectively. The idea was to test whether the impact of wage inequality on firm performance is larger in low inequality firms. Using OLS, we found no significant differences in the elasticities for both sub-samples. In contrast, 2SLS estimates supported, for all instrumented wage inequality indicators, the existence of a positive and hump-shaped relationship between wage dispersion and firm performance. Finally, we tested for a non-linear relationship using dummy variables (two or more) indicating the magnitude of the intra-firm wage inequality. This methodology led to insignificant results using both OLS and 2SLS regressions. In sum, we found some evidence in favour of a hump-shaped relationship. However, results (available on request) were not very robust. 
tively homogeneous, wage differentials stimulate workers' effort and their productivity. To put it differently, these models suggest that firms should establish a differentiated prize structure and award the largest prize to the most productive workers. Lazear's model $(1989,1995)$ of 'hawks' and 'doves' suggests that it is profitable for a firm to: i) adequately sort out workers at the hiring stage, and ii) adjust the compensation scheme to the characteristics of the workforce (i.e. the hierarchical level). This model shows that if the majority of the workforce adopts a sabotage or non-cooperative behaviour, a more compressed wage structure should be preferred. According to this theory, our sample is essentially composed of 'doves'. To put it in another way, it is because the majority of the workforce adopts a cooperative behaviour that firms can achieve a higher performance by implementing a more dispersed wage structure. However, our findings offer no support to the 'fairness, morale and cohesiveness' theories (Akerlof and Yellen 1990; Levine, 1991). Indeed, these theories suggest a negative relationship between intra-firm wage dispersion and firm performance.

\section{Composition of the Workforce}

According to the 'New Economics of Personnel' (Lazear 1995), we should expect the elasticity of firm performance with respect to pay inequality to be influenced by the composition of the workforce. In particular, various theories suggest that the relationship between pay dispersion and firm performance depends upon the proportion of white- and blue-collar workers within the firm. In this section, we test this hypothesis by letting our intra-firm wage dispersion indicators interact with a dummy variable that is equal to one if the share of white-collar workers within the firm is larger than $50 \%$ and zero otherwise. The results of this new specification are presented in Table 3.

Whatever the indicator used for intra-firm wage dispersion, OLS estimates show that the intensity of the relationship between pay dispersion and performance is significantly lower in firms that are essentially composed of white-collar workers. Indeed, the point estimates vary between 2.77 and 0.16 for bluecollar workers and between 1.29 and 0.09 for white-collar workers. At sample means, this yields an elasticity of between 0.70 and 0.48 for blue-collar workers and of between 0.24 and 0.10 for white-collar workers. In sum, results suggest that following a $10 \%$ rise in wage inequality, profits per capita increase by approximately 3.8 percentage points more in firms that are essentially composed of blue-collar workers. 2SLS estimates, reported in Table 3, show a positive impact of wage inequality on firm performance. Yet, while regression co- 
efficients associated to the interaction variables still have a negative sign, none of them are statistically significant. This finding might be due to a loss of information deriving from the instrumenting of our wage inequality indicators. Nevertheless, it also indicates that results from OLS regressions have to be considered with caution.

Why might the effect of pay dispersion on firm performance be different for blue- and white-collar workers? As suggested by Winter-Ebmer and Zweimüller (1999), a first possible explanation is that piece rates are more frequently used in firms with a majority of blue-collar workers. The point is that the implementation of piece rates increases wage dispersion but also performance because, in general, workers will put in more effort and top-performers will stay in these firms. Another argument may be that, on average, white-collar workers have a higher degree of autonomy in their jobs, more responsibilities and superior career prospects (Winter-Ebmer and Zweimüller 1999). Therefore, their level of effort is thought to be more determined by their intrinsic motivation. To put it differently, strong incentive schedules such as 'pay-for-performance', which in general need more monitoring, could be seen as a threat to their autonomy by white-collar workers, and as such crowd out their intrinsic motivation and reduce the intensity of their effort (Frey 1997). Our findings can also be interpreted on the basis of the theory of Milgrom (1988) and Milgrom and Roberts (1990). Indeed, monitoring costs are likely to be higher for whitecollar workers. Therefore, white-collar workers may have more incentives to: i) withhold information from managers in order to increase their influence and, ii) engage in costly rent-seeking activities instead of productive work. This could be an additional reason why the elasticity between wage dispersion and profits might be lower for white-collar workers.

\section{Monitoring Environment}

Another important question is whether the relationship between wage dispersion and firm performance is affected by the degree of monitoring within the firm. To address this question, we have let our intra-firm wage dispersion indicators interact with a dummy variable that is equal to one if the share of the workforce with supervising authority over co-workers is lower than or equal to $20 \%$ and zero otherwise.

OLS estimates of this new specification, presented in Table 4, show that the elasticity of performance to pay dispersion is positive and significantly higher among firms with a high degree of monitoring ('supervising firms'). At sample means, the elasticity of profits per capita to intra-firm pay dispersion ranges be- 


\section{THIERRY LALLEMAND/ROBERT PLASMAN/FRANÇOIS RYCX}

Table 3

Firm-level Performance and the Composition of the Workforce, OLS vs. 2SLS

\begin{tabular}{|c|c|c|c|c|c|c|c|c|}
\hline Dependent variable & & & & ofits per e & aployee ${ }^{1}(1$ & & & \\
\hline & & & & & & & & \\
\hline Intercept & $\begin{array}{l}6.07^{* *} \\
(0.67)\end{array}$ & $\begin{array}{l}6.05^{* *} \\
(0.66)\end{array}$ & $\begin{array}{l}6.12 * * \\
(0.66)\end{array}$ & $\begin{array}{l}6.49^{* *} \\
(0.66)\end{array}$ & $\begin{array}{l}5.43^{* *} \\
(0.66)\end{array}$ & $\begin{array}{l}5.68^{* *} \\
(0.65)\end{array}$ & $\begin{array}{l}5.81^{* *} \\
(0.65)\end{array}$ & $\begin{array}{l}6.71 * * \\
(0.67)\end{array}$ \\
\hline $\begin{array}{l}\text { Residual pay } \\
\text { inequality (RPI) }\end{array}$ & $\begin{array}{l}2.77^{*} \\
(1.14)\end{array}$ & & & & $\begin{array}{l}9.03^{* *} \\
(1.90)\end{array}$ & & & \\
\hline RPI * White-collar ${ }^{3}$ & $\begin{array}{l}-1.48^{\circ 0} \\
(0.97)\end{array}$ & & & & $\begin{array}{l}-1.22 \\
(1.10)\end{array}$ & & & \\
\hline $\begin{array}{l}\text { Standard deviation of } \\
\text { wages (SD) }\end{array}$ & & $\begin{array}{l}2.45^{* *} \\
(0.77)\end{array}$ & & & & $\begin{array}{l}4.37^{* *} \\
(0.93)\end{array}$ & & \\
\hline SD * White-collar ${ }^{3}$ & & $\begin{array}{l}-1.34^{*} \\
(0.62)\end{array}$ & & & & $\begin{array}{l}-0.77 \\
(0.69)\end{array}$ & & \\
\hline $\begin{array}{l}\text { Coefficient of } \\
\text { variation of wages } \\
(\mathrm{CV})^{4}\end{array}$ & & & $\begin{array}{c}1.44 * \\
(0.57)\end{array}$ & & & & $\begin{array}{l}3.11 * * \\
(0.66)\end{array}$ & \\
\hline $\mathrm{CV} *$ White-collar $^{3}$ & & & $\begin{array}{c}-1.03^{*} \\
(0.50)\end{array}$ & & & & $\begin{array}{l}-0.65 \\
(0.56)\end{array}$ & \\
\hline $\begin{array}{l}\text { Max-min ratio of } \\
\text { wages (MM) }\end{array}$ & & & & $\begin{array}{l}0.16^{* *} \\
(0.04)\end{array}$ & & & & $\begin{array}{l}0.28^{* *} \\
(0.06)\end{array}$ \\
\hline MM * White-collar ${ }^{3}$ & & & & $\begin{array}{l}-0.07^{\circ 0} \\
(0.05)\end{array}$ & & & & $\begin{array}{c}-0.07 \\
(0.05)\end{array}$ \\
\hline $\begin{array}{l}\text { Worker characte- } \\
\text { ristics }^{5}\end{array}$ & Yes & Yes & Yes & Yes & Yes & Yes & Yes & Yes \\
\hline Firm characteristics ${ }^{6}$ & Yes & Yes & Yes & Yes & Yes & Yes & Yes & Yes \\
\hline Adjusted $\mathrm{R}^{2}$ & 0.39 & 0.40 & 0.39 & 0.40 & 0.44 & 0.44 & 0.44 & 0.44 \\
\hline F-stat & $67.02 * *$ & $70.02 * *$ & $66.79 * *$ & $68.68^{* *}$ & $72.10^{* *}$ & $72.83^{* *}$ & $72.88 * *$ & $72.87 * *$ \\
\hline $\begin{array}{l}\text { Hausman test: } \\
\text { p-value }\end{array}$ & & & & & 0.00 & 0.00 & 0.00 & 0.00 \\
\hline Number of employees & 17,490 & 17,490 & 17,490 & 17,490 & 17,490 & 17,490 & 17,490 & 17,490 \\
\hline Number of firms & 397 & 397 & 397 & 397 & 397 & 397 & 397 & 397 \\
\hline
\end{tabular}

Notes: $* * / * / \% / 0 \circ$ indicate significance at the $1,5,10$ and $15 \%$ level, respectively. White (1980) heteroscedasticity consistent standard errors are reported between brackets.

1 Estimated by the firm annual gross operating surplus per worker.

2 Conditional indicator for within-firm wage dispersion (i.e. standard errors of wage regressions run for each firm separately).

3 'White-collar' is a dummy variable that is equal to 1 if the share of white-collar workers within the firm is larger than $50 \%$ and 0 otherwise.

4 Individual gross hourly wages include overtime paid, premiums for shift work, night work and/or weekend work and bonuses, i.e. irregular payments which do not occur during each pay period, such as pay for holiday, 13 th month and profit sharing.

5 Share of the workforce that: i) at most has attended lower secondary school, ii) has more than 10 years of tenure and iii) is younger than 25 and older than 50 years, respectively. The share of women, the share of blue-collar workers and the share of the workers supervising co-workers are also included.

6 Sectoral affiliation (5 dummies), size of the firm (number of workers), and level of wage bargaining ( 2 dummies). 
tween 0.71 and 0.47 in firms with a high degree of monitoring and between 0.33 and 0.17 in firms with a low degree of monitoring. 2SLS estimates also report a positive and significant effect of wage dispersion on firm performance. However, while coefficients associated to the interaction variables remain negative, none of them are significantly different from zero. This result suggests that findings from OLS regressions should be interpreted with care. Yet, our instrumenting procedure may have led to some loss of information.

Overall, findings reported in Table 4 emphasize the importance of a correct match between the compensation scheme and the monitoring environment within a firm. To put it differently, results appear to be consistent with the hypothesis that

'it is not so much the choice of pay system that drives the organisational outcomes, but the combination of pay system and monitoring environment' (Belfield and Marsden 2003: 469).

It is also noteworthy that our descriptive statistics indicate that 'supervising firms' have a greater proportion of blue-collar workers $(66 \%$ vs. $43 \%)$ and that their mean conditional pay inequality is larger $(0.20$ vs. 0.15$)$. Hence, our findings seem to be consistent with Milgrom (1988) and Milgrom and Roberts (1990), who suggest a lower pay spread within firms that are mainly composed of white-collar workers.

\section{CONCLUSION}

This paper examines the relationship between intra-firm wage dispersion and firm performance in large firms of the Belgian private sector using a unique matched employer-employee data set. This data set has been obtained by merging the 'Structure of Earnings Survey' with the 'Structure of Business Survey' for the year 1995. The former contains detailed information on firm-level characteristics (e.g. sector of activity, size of the firm, and level of wage bargaining) and on individual workers (e.g. gross hourly wages, bonuses, age, education, sex, and occupation). The latter provides firm-level information on financial variables (e.g. gross operating surplus, value added, and value of production).

Our methodology is consistent with that of Winter-Ebmer and Zweimüller (1999). It rests upon a two-step estimation procedure. Firstly, we compute conditional intra-firm wage differentials by taking the standard errors of wage regressions run for each firm separately. Next, we use these conditional wage differentials as an explanatory variable in a firm-level performance regression. As a sensitivity test, we also analyse the impact of unconditional indicators of intra-firm wage dispersion on firm performance. These indicators include the 


\section{THIERRY LALLEMAND/ROBERT PLASMAN/FRANÇOIS RYCX}

Table 4

Firm-level Performance and the Monitoring Environment, OLS vs. 2SLS

\begin{tabular}{|c|c|c|c|c|c|c|c|c|}
\hline \multirow{3}{*}{$\begin{array}{l}\text { Dependent variable } \\
\text { Intercept }\end{array}$} & \multicolumn{8}{|c|}{ Profits per employee ${ }^{1}(\ln )$} \\
\hline & \multicolumn{4}{|c|}{ OLS } & \multicolumn{4}{|c|}{ 2SLS } \\
\hline & $\begin{array}{l}6.04 * * \\
(0.66)\end{array}$ & $\begin{array}{l}5.94 * * \\
(0.66)\end{array}$ & $\begin{array}{l}6.04^{* *} \\
(0.66)\end{array}$ & $\begin{array}{l}6.40 * * \\
(0.65)\end{array}$ & $\begin{array}{l}5.39 * * \\
(0.64)\end{array}$ & $\begin{array}{l}5.60^{* *} \\
(0.64)\end{array}$ & $\begin{array}{l}5.71^{* *} \\
(0.64)\end{array}$ & $\begin{array}{l}6.62 * * \\
(0.67)\end{array}$ \\
\hline $\begin{array}{l}\text { Residual pay } \\
\text { inequality (RPI) }\end{array}$ & $\begin{array}{l}3.11^{* *} \\
(1.14)\end{array}$ & & & & $\begin{array}{l}8.88^{* *} \\
(1.90)\end{array}$ & & & \\
\hline $\begin{array}{l}\text { RPI * Low } \\
\text { monitoring }\end{array}$ & $\begin{array}{l}-1.86^{*} \\
(0.83)\end{array}$ & & & & $\begin{array}{l}-1.06 \\
(0.89)\end{array}$ & & & \\
\hline $\begin{array}{l}\text { Standard deviation of } \\
\text { wages }(\mathrm{SD})^{4}\end{array}$ & & $\begin{array}{l}2.32 * * \\
(0.80)\end{array}$ & & & & $\begin{array}{l}4.27 * * \\
(0.93)\end{array}$ & & \\
\hline $\mathrm{SD}^{*}$ Low monitoring ${ }^{3}$ & & $\begin{array}{l}-0.84^{\circ} \\
(0.55)\end{array}$ & & & & $\begin{array}{c}-0.42 \\
(0.56)\end{array}$ & & \\
\hline $\begin{array}{l}\text { Coefficient of } \\
\text { variation of wages } \\
(\mathrm{CV})^{4}\end{array}$ & & & $\begin{array}{l}1.30^{*} \\
(0.57)\end{array}$ & & & & $\begin{array}{l}3.00 * * \\
(0.66)\end{array}$ & \\
\hline $\mathrm{CV}^{*}$ Low monitoring ${ }^{3}$ & & & $\begin{array}{c}-0.67^{\circ} \\
(0.46)\end{array}$ & & & & $\begin{array}{l}-0.24 \\
(0.46)\end{array}$ & \\
\hline $\begin{array}{l}\text { Max-min ratio of } \\
\text { wages (MM) }\end{array}$ & & & & $\begin{array}{l}0.18^{* *} \\
(0.05)\end{array}$ & & & & $\begin{array}{l}0.28^{* *} \\
(0.06)\end{array}$ \\
\hline $\begin{array}{l}\text { MM * Low } \\
\text { monitoring }\end{array}$ & & & & $\begin{array}{r}-0.07^{\circ} \\
(0.04)\end{array}$ & & & & $\begin{array}{l}-0.03 \\
(0.04)\end{array}$ \\
\hline $\begin{array}{l}\text { Worker } \\
\text { characteristics }\end{array}$ & Yes & Yes & Yes & Yes & Yes & Yes & Yes & Yes \\
\hline Firm characteristics ${ }^{6}$ & Yes & Yes & Yes & Yes & Yes & Yes & Yes & Yes \\
\hline Adjusted $\mathrm{R}^{2}$ & 0.39 & 0.39 & 0.39 & 0.40 & 0.44 & 0.44 & 0.44 & 0.44 \\
\hline F-stat & $67.29 * *$ & $67.73^{* *}$ & $64.43 * *$ & $68.38^{* *}$ & $71.78^{* *}$ & $71.15^{* *}$ & $71.00 * *$ & $71.09 * *$ \\
\hline $\begin{array}{l}\text { Hausman test: } \\
\text { p-value }\end{array}$ & & & & & 0.00 & 0.00 & 0.00 & 0.00 \\
\hline Number of employees & 17,490 & 17,490 & 17,490 & 17,490 & 17,490 & 17,490 & 17,490 & 17,490 \\
\hline Number of firms & 397 & 397 & 397 & 397 & 397 & 397 & 397 & 397 \\
\hline
\end{tabular}

Notes: $* * / * / \%^{\circ \circ}$ indicate significance at the $1,5,10$ and $15 \%$ level, respectively. White (1980) heteroscedasticity consistent standard errors are reported between brackets.

1 Estimated by the firm annual gross operating surplus per worker.

2 Conditional indicator for within-firm wage dispersion (i.e. standard errors of wage regressions run for each firm separately).

3 'Low monitoring' is a dummy variable that is equal to 1 if the share of the workforce with supervising authority over co-workers is lower than or equal to $20 \%$ and 0 otherwise.

4 Individual gross hourly wages include overtime paid, premiums for shift work, night work and/or weekend work and bonuses, i.e. irregular payments which do not occur during each pay period, such as pay for holiday, 13 th month and profit sharing.

5 Share of the workforce that: i) at most has attended lower secondary school, ii) has more than 10 years of tenure and iii) is younger than 25 and older than 50 years, respectively. The share of women, the share of blue-collar workers and the share of the workers supervising co-workers are also included.

6 Sectoral affiliation (5 dummies), size of the firm (number of workers), and level of wage bargaining ( 2 dummies). 
standard deviation, the coefficient of variation and the max-min ratio of gross hourly wages within the firm. The performance of a firm is measured by its gross operating surplus per worker. It is a good proxy for the firm's per capita profits. We address the potential simultaneity problem between profits and wage dispersion using information from the Belgian income tax system. More precisely, we use two-stage least squares (2SLS) and instrument the dispersion of wages including bonuses by the intra-firm standard deviation of income taxes on gross earnings excluding bonuses.

To our knowledge, this paper is one of the first to examine the effect of intrafirm wage dispersion on firm performance in the private sector using both a conditional wage inequality indicator and direct information on firm performance. It is also one of the few, with Bingley and Eriksson (2001) and Heyman (2002), to consider potential simultaneity problems. Empirical findings, reported in this paper, support the existence of a positive and significant relationship between wage inequality and firm performance. Moreover, we find that the intensity of this relationship is stronger for blue-collar workers and within firms with a high degree of monitoring. These findings are more in line with the 'tournament' models (Lazear and Rosen 1981) than with the 'fairness, morale and cohesiveness' models (Akerlof and Yellen 1990, Levine 1991).

Results presented in this paper are quite similar to those reported for Austria by Winter-Ebmer and Zweimüller (1999). Indeed, their estimates suggest the existence of a positive and hump-shaped relationship between intra-firm wage dispersion and firm performance, for both blue- and white-collar workers. They also show that the overall pattern appears more monotonic for blue-collar workers. Yet, their study differs from ours in several ways. Firstly, WinterEbmer and Zweimüller (1999) have no direct information on the financial performance of the firms. Therefore, they construct their own performance indicator, i.e. standardised wages. In contrast, we use as a dependant variable the gross operating surplus per worker. Secondly, they have panel data covering the period 1975-91, while the present study relies on a single cross-section relative to 1995 . Thirdly, they perform fixed effects and group-means regressions in order to identify if their OLS estimates are driven by short- or long-term considerations. Finally, they do not address the potential problem of simultaneity between wage dispersion and firm performance, while we instrument wage inequality by the dispersion in income taxes per firm. Be that as it may, both studies suggest that wage dispersion is beneficial for firm performance up to a certain point.

Future research in this area should rely on matched employer-employee panel data so as to control for the non observed characteristics of the workers and/or firms. Unfortunately, at the moment such data do not exist for Belgium. 


\section{THIERRY LALLEMAND/ROBERT PLASMAN/FRANÇOIS RYCX}

It would also be interesting to extend the analysis to small firms using a conditional measure of intra-firm wage dispersion. However, this option requires a rich data set with a larger number of observations per (small) firm.

\section{APPENDIX}

Table Al

Means and Standard Deviations of Variables - Workers' Level (First Step)

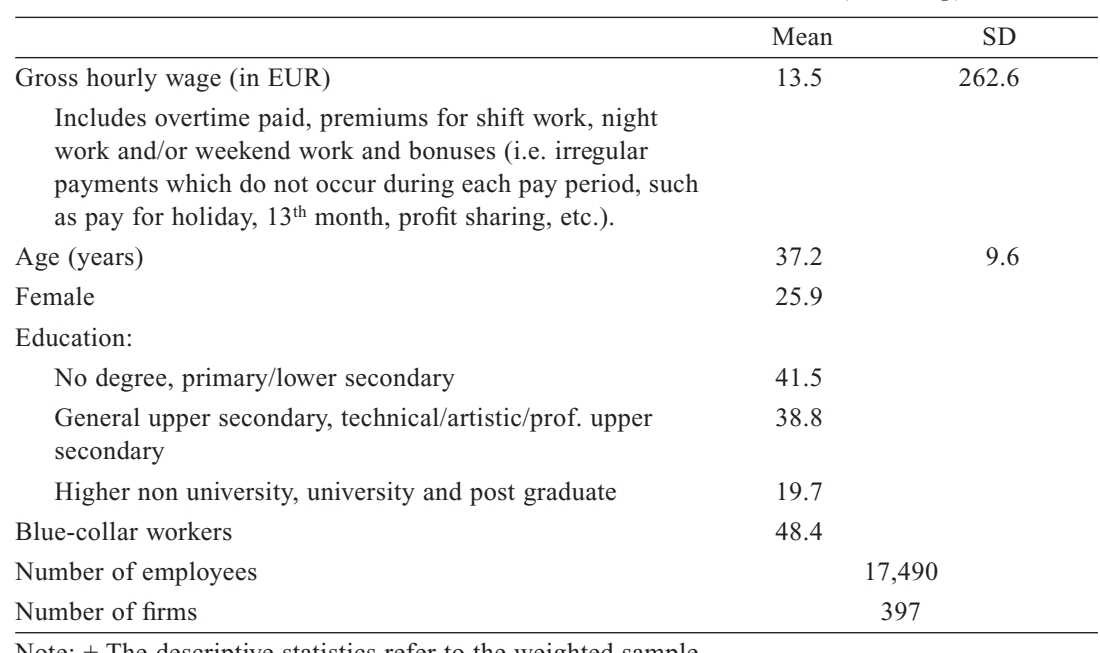

Note: + The descriptive statistics refer to the weighted sample. 


\section{INTRA-FIRM WAGE DISPERSION AND FIRM PERFORMANCE}

Table A2

Means and Standard Deviations of Variables - Firm Level (Second Step)

\begin{tabular}{|c|c|c|}
\hline & Mean & SD \\
\hline \multicolumn{3}{|l|}{ I. Firm performance } \\
\hline \multicolumn{3}{|l|}{$\begin{array}{l}\text { Estimated by the firm annual gross operating surplus per } \\
\text { worker. The gross operating surplus corresponds to the } \\
\text { difference between value added at factor costs and total } \\
\text { personnel expenditures. }\end{array}$} \\
\hline \multicolumn{3}{|l|}{ II. Intra-firm wage dispersion } \\
\hline \multicolumn{3}{|l|}{$\begin{array}{l}\text { Conditional measure of the intra-firm wage dispersion } \\
\text { (i.e. standard errors of wage regressions run for each firm } \\
\text { separately) }\end{array}$} \\
\hline Standard deviation of wages ${ }^{1}$ & 0.24 & 0.10 \\
\hline Coefficient of variation of wages ${ }^{1}$ & 0.29 & 0.14 \\
\hline Max-Min ratio of wages ${ }^{1}$ & 3.17 & 1.60 \\
\hline \multicolumn{2}{|l|}{ III. Control variables } & a) Share of the workforce \\
\hline Age $<25$ years & 10.2 & 11.5 \\
\hline Age $>50$ years & 9.3 & 8.5 \\
\hline Female & 30.1 & 27.0 \\
\hline Low educated (no degree, primary or lower secondary) & 40.6 & 31.0 \\
\hline Blue-collar & 52.4 & 34.2 \\
\hline Tenure $>10$ years & 42.2 & 23.4 \\
\hline Supervising their co-workers (monitoring) & 15.1 & 13.4 \\
\hline \multicolumn{3}{|l|}{ b) Firm characteristics } \\
\hline Size (number of workers) & 480.4 & 621.1 \\
\hline \multicolumn{3}{|l|}{ Level of wage bargaining: } \\
\hline CA only at national and/or sectoral level ${ }^{2}$ & 41.7 & \\
\hline $\mathrm{CA}$ at the company level ${ }^{2}$ & 53.5 & \\
\hline Other & 4.8 & \\
\hline \multicolumn{3}{|l|}{ Sector: } \\
\hline Manufacturing (D) & 63.5 & \\
\hline Electricity, gas and water supply (E) & 0.2 & \\
\hline Construction $(\mathrm{F})$ & 3.6 & \\
\hline $\begin{array}{l}\text { Wholesale and retail trade; repair of motor vehicles } \\
\text { (G) }\end{array}$ & 18.6 & \\
\hline Transport, storage and communication (I) & 3.7 & \\
\hline Real estate, renting and business activities (K) & 10.6 & \\
\hline Number of employees & \multicolumn{2}{|c|}{17,490} \\
\hline Number of firms & & \\
\hline
\end{tabular}

Notes: + The descriptive statistics refer to the weighted sample.

1 Individual gross hourly wages include overtime paid, premiums for shift work, night work and/or weekend work and bonuses, i.e. irregular payments which do not occur during each pay period, such as pay for holiday, 13th month and profit sharing.

2 CA stands for collective labour agreement. 


\section{THIERRY LALLEMAND/ROBERT PLASMAN/FRANÇOIS RYCX}

\section{REFERENCES}

Adams, Stacy J. (1963). Toward an Understanding of Inequity, Journal of Abnormal and Social Psychology. 75: 422-436.

Akerlof, George A. and Janet L. Yellen (1988). Fairness and Unemployment, American Economic Review, Papers and Proceedings. 78: 44-49.

Akerlof, George A. and Janet L. Yellen (1990). The Fair Wage-Effort Hypothesis and Unemployment, Ouarterly Journal of Economics. 105: 255-283.

Belfield, Richard and David Marsden (2003). Performance Pay, Monitoring Environments, and Establishment Performance, International Journal of Manpower. 24: 452-471.

Bingley, Paul and Tor Eriksson (2001). Pay Spread and Skewness, Employee Effort and Firm Productivity, Working Paper: 01-2, Department of Economics, Faculty of Business Administration, Aarhus, Denmark.

Blau, Peter M. (1955). The Dynamics of Bureaucracy: A Study of Interpersonal Relations in Two Government Agencies. Chicago: University of Chicago Press.

Bloom, Matt (1999). The Performance Effects of Pay Dispersion on Individuals and Organizations, Academy of Management Journal. 42: 25-40.

Cowherd, Douglas M. and David I. Levine (1992). Product Quality and Pay Equity between Lowerlevel Employees and Top Management: An Investigation of Distributive Justice Theory, Administrative Science Quarterly. 37: 302-320.

DeBrock, Lawrence, Wallace Hendricks and Roger Koenker (2001). Pay and Performance: The Impact of Salary Distribution on Firm Level Outcomes in Baseball, Unpublished Paper, Department of Economics, University of Illinois, Urbana-Champaign.

Demunter, Christophe (2000). Structure and Distribution of Earnings Survey: Analysis 1995, Statistics Belgium Working Paper, Statistics Belgium, Belgium.

Depken, Craig A. (2000). Wage Disparity and Team Productivity. Evidence from Major League Baseball, Economics Letters. 67: 87-92.

Eriksson, Tor (1999). Executive Compensation and Tournament Theory: Empirical Tests on Danish Data, Journal of Labor Economics. 17: 262-280.

Frey, Bruno S. (1997). Not Just for the Money: An Economic Theory of Personal Motivation. Cheltenham: Edward Elgar.

Frey, Bruno S. and Margit Osterloh (1997). Sanktionen oder Seelenmassage? Motivationale Grundlagen der Unternehmensführung, Die Betriebswirtschaft. 57: 307-321.

Frick, Bernd, Joachim Prinz and Karina Winkelmann (2003). Pay Inequalities and Team Performance: Empirical Evidence from the North American Major Leagues, International Journal of Manpower. 24: 472-488

Gibbons, Robert S. and Michael Waldman (1999). Careers in Organizations: Theory and Evidence, in: Orley C. Ashenfelter and David Card (eds.), Handbook of Labor Economics, Vol. 3B, Chapter 36. Amsterdam: Elsevier Science: 2373-2437.

Gomez, Rafael (2002). Salary Compression and Team Performance: Evidence from the National Hockey League, Zeitschrift für Betriebswirtschaf: Ergänzungsheft 'Sportökonomie'. 72: 203-220.

Harder, Joseph W. (1992). Play for Pay: Effects of Inequity in a Pay-for-performance Context, $A d$ ministrative Science Quarterly. 37: 321-335.

Hausman, Jerry A. (1976). Specification Tests in Econometrics, Econometrica. 46: 1251-1271.

Heyman, Fredrik (2002). Pay Inequality and Firm Performance: Evidence from Matched Employeremployee Data, FIEF Working Paper: 186, Trade Union Institute for Economic Research, Stockholm, Sweden.

Hibbs, Douglas A. Jr. and Hakan Locking (2000). Wage Dispersion and Productive Efficiency: Evidence for Sweden, Journal of Labor Economics. 18: 755-782.

Homans, George C. (1961). Social Behavior: Its Elementary Forms. New York: Harcourt Brace Jovanovich.

Lazear, Edward P. (1989). Pay Equality and Industrial Politics, Journal of Political Economy. 97 : 561-580. 


\section{INTRA-FIRM WAGE DISPERSION AND FIRM PERFORMANCE}

Lazear, Edward P. (1995). Personnel Economics. Cambridge (Mass.): MIT Press.

Lazear, Edward P. and Sherwin Rosen (1981). Rank-order Tournaments as Optimum Labor Contracts, Journal of Political Economy. 89: 841-864.

Lehmann, Erik and Ulrich Wacker (2000). Messung und Steuerung von Einkommensungleichheiten in Organisationen, in: Uschi Backes-Gellner, Matthias Kräkel, Bernd Schauenberger and Günter Steiner (eds.), Flexibilisierungstendenzen in der betrieblichen Personalpolitik. Munich: Rainer Hampp Verlag: 109-128.

Leonard, Johnathan S. (1990). Executive Pay and Firm Performance, Industrial and Labor Relations Review. 43: 13-29.

Levine, David I. (1991). Cohesiveness, Productivity and Wage Dispersion, Journal of Economic Behavior and Organization. 15: 237-255.

Main, Brian G., Charles A. O'Reilly and James Wade (1993). Top Executive Pay: Tournament or Teamwork?, Journal of Labor Economics. 11: 606-628.

McLaughlin, Kenneth J. (1988). Aspects of Tournaments Models: A Survey, Journal of Labor Economics. 15: 403-430.

Milgrom, Paul (1988). Employment Contracts, Influence Activities and Efficient Organisation Design, Journal of Political Economy. 96: 42-60.

Milgrom, Paul and John Roberts (1990). The Efficiency of Equity in Organisational Decision Processes, American Economic Review, Papers and Proceedings. 80: 154-159.

Pfeffer, Jeffrey and Nancy Langton (1993). The Effect of Wage Dispersion on Satisfaction, Productivity, and Working Collaboratively: Evidence from College and University Faculty, Administrative Science Quarterly. 38: 382-407.

Richards, Donald G. and Robert C. Guell (1998). Baseball Success and the Structure of Salaries, Applied Economics Letters. 5: 291-296.

Solow, Robert M. (1979). Another Possible Source of Wage Stickiness, Journal of Macroeconomics. 1: $79-82$.

White, Howard (1980). A Heteroscedasticity-consistent Covariance Matrix Estimator and a Direct Test for Heteroscedasticity, Econometrica. 48: 817-830.

Winter-Ebmer, Rudolf and Josef Zweimüller (1999). Intra-firm Wage Dispersion and Firm Performance, Kyklos. 52: 555-572.

\section{SUMMARY}

This paper examines the relationship between intra-firm wage dispersion and firm performance in large Belgian firms using a unique matched employer-employee data set. On the basis of the WinterEbmer and Zweimüller's (1999) methodology, we find a positive and significant relationship between intra-firm wage dispersion and profits per capita, even when controlling for individual and firm characteristics and addressing potential simultaneity problems. Results also suggest that the intensity of this relationship is stronger for blue-collar workers and within firms with a high degree of monitoring. These findings are more in line with the 'tournament' models than with the 'fairness, morale and cohesiveness' models.

\section{ZUSAMMENFASSUNG}

Mit Hilfe eines 'gematchten’ Arbeitgeber-Arbeitnehmer-Datensatzes großer belgischer Unternehmen wird im vorliegenden Beitrag der Zusammenhang zwischen betriebsinterner Lohndifferentiale und Unternehmensperformance untersucht. Basierend auf der Methodologie von Winter-Ebmer und Zweimüller (1999), lässt sich selbst dann eine signifikant positive Beziehung zwischen betriebsinternen Lohnunterschieden und Unternehmensperformance zeigen, wenn nicht nur dem möglichen Si- 


\section{THIERRY LALLEMAND/ROBERT PLASMAN/FRANÇOIS RYCX}

multanitätsproblem Rechnung getragen wird, sondern wenn zusätzlich auch Individuen und Firmencharakteristika überprüft werden. Außerdem implizieren die Ergebnisse, dass die Wirkung dieses Zusammenhangs für Arbeiter und in Betrieben mit hohen 'Überwachungsaktivitäten' besonders stark ist. Diese Befunde sind kompatibel mit der Turniertheorie und lassen sich nicht mit dem 'Fairnessund Kohäsionsansatz' erklären.

\section{RÉSUMÉ}

Cet article analyse la relation entre la dispersion salariale intra-firme et la performance au sein de grandes entreprises belges à partir de données appareillées employeur-employé. Sur base de la méthodologie de Winter-Ebmer et Zweimüller (1999), nous trouvons une relation positive et significative entre la dispersion salariale au sein des entreprises et les profits par tête. Ce résultat est obtenu en contrôlant les caractéristiques des travailleurs et des entreprises ainsi qu'en abordant le problème potentiel de la simultanéité. Nos estimations indiquent également que l'intensité de la relation est plus forte pour les ouvriers ainsi qu'au sein des entreprises avec un degré élevé de monitoring. Ces résultats correspondent davantage à la théorie des 'tournois' qu'aux modèles de 'coopération'. 